\title{
PENGARUH PAKET EDUKASI TANDA BAHAYA KEHAMILAN MELALUI MEDIA BOOKLET, AUDIOVISUAL DAN KOMBINASI TERHADAP PENGETAHUAN DAN SIKAP IBU HAMIL
}

\author{
THE EFFECT OF EDUCATION PACKAGES OF PREGNANCY \\ HAZARDS THROUGH BOOKLET, AUDIOVISUAL AND \\ COMBINATION MEDIA ON KNOWLEDGE AND ATTITUDE OF \\ PREGNANT WOMEN
}

\author{
Senja Atika Sari $\mathrm{HS}^{1}$, Suhendar Sulaeman ${ }^{2}$ Idriani $^{3}$ \\ ${ }^{1}$ Akper Dharma Wacana Metro \\ ${ }_{2}$ Universitas Muhammadiyah Jakarta
}

\begin{abstract}
ABSTRAK
Tanda bahaya kehamilan dapat terjadi secara mendadak, dan biasanya tidak dapat diperkirakan sebelumnya. Oleh karena itu dibutuhkan adanya edukasi untuk meningkatkan pengetahuan pada ibu hamil. Tujuan : tujuan penelitian ini adalah mengetahui Pengaruh paket edukasi tanda bahaya kehamilan melalui media booklet, audiovisual dan kombinasi booklet audiovisual terhadap pengetahuan dan sikap ibu hamil. Metode : penelitian ini menggunakan pendekatan kuantitatif dengan desain penelitian quasi experimental dengan rancangan one group pretest-posttest. Sampel yang digunakan sebanyak 10 orang untuk tiap kelompok perlakuan, teknik purposive sampling. Alat ukur yang digunakan berupa kuesioner yang telah melalui uji validitas dan reabilitas. Analisis data menggunakan uji paired sample $t$ test dan one way anova. Hasil analisis menunjukan bahwa terdapat pengaruh paket edukasi tanda bahaya kehamilan melalui media booklet, audiovisual \& kombinasi terhadap pengetahuan dan sikap $(\mathrm{p}<\alpha 0,05)$. Media kombinasi (booklet \& audiovisual) paling berpengaruh terhadap peningkatan pengetahuan,dan sikap ibu hamil tentang tanda bahaya kehamilan. Kesimpulan : media kombinasi (booklet dan audiovisual) lebih efektif dibandingkan menggunakan media secara terpisah. Oleh karena itu penggunaan media kombinasi dapat diterapkan pada pelayanan kesehatan untuk meningkatkan pengetahuan dan sikap ibu hamil.
\end{abstract}

Kata Kunci : Paket edukasi, pengetahuan dan sikap

\begin{abstract}
The danger sign of pregnancy can occur suddenly, and is usually unpredictable. Therefore there is a need for education to increase knowledge in pregnant women. Objective: the purpose of this study was to determine the effect of pregnancy alarm education packages through booklet, audiovisual media and audiovisual booklet combinations on the knowledge and attitudes of pregnant women. Method: this study uses a quantitative approach with a quasi experimental research design with the design of one group pretest-posttest. The sample used was 10 people for each treatment group, purposive sampling technique. The measuring instrument used is a questionnaire that has been tested for validity and reliability. Data analysis used paired sample t test and one way anova test. The results of the analysis showed that there was an effect of the pregnancy alarm education package through booklet, audiovisual \& combination media on knowledge and attitudes $(p<50.05)$. Combined media (booklet \& audiovisual) has the most influence on increasing knowledge and attitudes of pregnant women about the danger signs of pregnancy. Conclusion: combination media (booklet and audiovisual) are more effective than using media separately. Therefore the use of combination media can be applied to health services to increase knowledge and attitudes of pregnant women.
\end{abstract}

Keywords: Educational package, attitude and knowledge 


\section{PENDAHULUAN}

Berdasarkan pencapaian target Sustainable Development Goals (SDGs) tahun 2015 tujuan ke-tiga, menjamin kehidupan yang sehat, meningkatkan kesejahteraan penduduk di segala usia, yaitu pada 2030. Targetnya mengurangi Angka Kematian Ibu hingga dibawah 70 per 100.000 kelahiran hidup, dan mengakhiri kematian bayi serta balita yang dapat dicegah dengan seluruh negara yaitu menurunkan angka kematian neonatal 12 per 1000 kelahiran hidup dan angka kematian balita 25 per 1000 kelahiran hidup pada tahun $2030^{1}$.

Mortalitas dan morbiditas wanita hamil dan bersalin merupakan masalah besar di dunia baik di negara maju maupun berkembang. Menurut Word Health Organization (WHO) tahun 2015 setiap hari, terdapat sekitar 830 wanita meninggal terkait dengan kehamilan dan persalinan di negara berkembang. Tingginya jumlah kematian ibu di beberapa wilayah di dunia mencerminkan rendahnya akses ke layanan kesehatan. Kematian ibu di negara-negara berkembang pada tahun 2015 adalah 239 per 100.000 kelahiran hidup, sementara di negara maju adalah 12 per 100.000 kelahiran hidup. Penyebab utama kematian ibu adalah perdarahan post partum (27,5\%), gangguan hipertensi $(14,0 \%)$ dan sepsis
$(10,7 \%)$. Selebihnya adalah karena abortus $(7,9 \%)$, dan penyebab lain $(9,6 \%)^{2}$.

Angka kematian Ibu (AKI) di Indonesia berdasarkan hasil Survei Demografi Kesehatan Indonesia (SDKI) tahun 2012 menunjukkan bahwa AKI mencapai 359/100.000 kelahiran hidup, angka ini jauh lebih tinggi dibandingkan SDKI tahun 2007 yaitu sebesar 228/100.000 kelahiran hidup. Terdapat lima penyebab kematian ibu yaitu karena perdarahan, hipertensi dalam kehamilan (HDK), dan infeksi ${ }^{3}$.

Tingginya Angka kematian Ibu (AKI) baik di dunia maupun di Indonesia diantaranya berkaitan dengan kehamilan. Sebagian besar kehamilan berakhir dengan persalinan namun 15-20 diantara $100 \mathrm{ibu}$ hamil mengalami gangguan kehamilan, persalinan dan nifas. Gangguan tersebut dapat terjadi secara mendadak, dan biasanya tidak dapat diperkirakan sebelumnya. Tanda bahaya pada kehamilan yang mungkin terjadi diantaranya adalah muntah yang terus dan tidak mau makan, demam tinggi, bengkak pada kaki, tangan dan wajah atau sakit kepala disertai kejang, janin dirasakan kurang bergerak dibandingkan sebelumnya, perdarahan pada hamil muda dan hamil tua, air ketuban pecah sebelum waktunya. Untuk dapat mencegah terjadinya masalah pada kehamilan, maka setiap ibu hamil harus dapat mengetahui dan mengenali tanda- 
tanda bahaya pada kehamilan sehingga keluarga dapat segera membawa ibu untuk mendapatkan pertolongan di fasilitas kesehatan terdekat secara tepat waktu. Apabila sejak awal ibu mengenali adanya gangguan dalam kehamilan maka ibu tidak akan terlambat mendapatkan pertolongan dari tenaga kesehatan. Oleh karena itu dibutuhkan adanya edukasi untuk meningkatkan pengetahuan pada ibu hamil 4

Pengetahuan adalah suatu proses mengingat dan mengenal kembali objek yang telah dipelajari melalui panca indra pada suatu bidang tertentu secara baik (Lesteri, 2015). Sedangkan sikap adalah kesiapan atau kesediaan untuk bertindak, dan bukan merupakan pelaksanaan motif tertentu. Fungsi sikap belum merupakan tindakan (reaksi terbuka) atau aktivitas, akan tetapi merupakan predisposisi perilaku (tindakan) atau reaksi tertutup ${ }^{5}$.

Salah satu tindakan yang dapat dilakukan untuk meningkatkan pengetahuan serta sikap masyarakat khususnya ibu hamil tentang tanda-tanda bahaya kehamilan adalah dengan memberikan edukasi atau pendidikan kesehatan. Edukasi atau pendidikan kesehatan sendiri merupakan kegiatan atau usaha dalam menyampaikan pesan kesehatan kepada masyarakat, kelompok atau individu. Dengan adanya pesan tersebut, maka masyarakat, kelompok ataupun individu mampu memperoleh pengetahuan tentang kesehatan yang lebih baik. Pengetahuan tersebut pada akhirnya diharapkan dapat berpengaruh terhadap perilaku. Dengan kata lain, adanya edukasi tersebut diharapkan dapat membawa perubahan perilaku kesehatan dari masyarakat ${ }^{6}$.

Promosi kesehatan menggunakan media edukasi merupakan salah cara yang tepat guna menyampaikan pesan kesehatan kepada masyarakat. Pemberian penjelasan, demonstrasi dan redemonstrasi pada paket edukasi akan menstimulasi secara aktif indera penglihatan, pendengaran, perasa dan perilaku, sehingga meningkatkan keberhasilan pembelajaran. Selain itu, paket edukasi yang menggunakan berbagai macam media dan metoda lebih mudah difahami oleh peserta didik. Hal ini karena belajar akan lebih aktif jika melibatkan lebih dari satu indera ${ }^{7}$.

Media edukasi yang digunakan untuk memberikan promosi kesehatan antara lain yaitu media audiovisual. Audiovisual memberikan pengaruh yang sangat besar dalam perubahan perilaku masyarakat. Media audiovisual memiliki dua elemen yang masing-masing mempunyai kekuatan yang akan bersinergi menjadi kekuatan yang besar. Media tersebut memberikan stimulus pada pendengaran dan penglihatan, sehingga hasil 
yang diperolah lebih maksimal. Hasil tersebut dapat terpenuhi karena pancaindera yang paling banyak menyalurkan pengetahuan ke otak adalah mata (kurang lebih 75\% sampai 87\%); sedangkan panca indra yang lain menyalurkan sekitar 13\% sampai $25 \%^{8}$.

Berdasarkan fenomena di atas, maka diperlukan adanya upaya pencegahan sejak dini terjadinya angka kesakitan maupun kematian pada ibu hamil melalui melalui promosi kesehatan secara spesifik dengan menggunakan paket edukasi tentang tanda bahaya kehamilan. Oleh karena itu, penulis tertarik untuk melakukan penelitian tentang " Pengaruh paket edukasi tanda bahaya kehamilan melalui media booklet, audiovisual dan kombinasi terhadap pengetahuan dan sikap ibu hamil”

\section{METODE}

Penelitian ini menggunakan desain eksperimen dengan rancangan one group pretest-postest. Pada rancangan ini, sampel dibagi dalam tiga kelompok dan ketiga kelompok diberikan perlakuan. Pengukuran pertama (pretest) dilakukan pada ketiga kelompok. Setelah pengukuran pertama (pretest) selanjutnya kelompok eksperimen satu diberikan perlakuan menggunakan audiovisual, kelompok dua menggunakan media booklet dan kelompok tiga menggunakan audiovisual dan booklet.
Setelah diberikan perlakuan kepada ketiga kelompok selanjutnya kembali dilakukan pengukuran (posttest). Subjek penelitian yang diambil adalah ibu hamil, sampel yang digunakan 30 orang dengan teknik purposive sampling. Sampel terbagi dalam 3 kelompok, yaitu kelompok responden yang diberikan intervensi edukasi dengan media audiovisual (kelompok intervensi I), kelompok responden yang diberikan intevensi edukasi dengan booklet (kelompok intervensi II), dan kelompok responden yang diberikan intervensi edukasi dengan media booklet dan audiovisual (kelompok intervensi III). Alat ukur yang dipergunakan adalah kuesioner. Tahap pengumpulan data meliputi, pengurusan perizinan dan persetujuan bagi calon responden. Sebelum perlakuan (penyuluhan kesehatan) dilakukan pengukuran pertama yaitu dengan membagikan kuesioner kepada responden yang telah memenuhi kriteria inklusi dan eksklusi, hasil jawaban responden akan dijadikan data pre -test. Selanjutnya peneliti melakukan penyuluhan tentang tanda bahaya kehamilan kepada responden yang telah memenuhi kriteria inklusi dan eksklusi. Setelah dilakukan perlakuan, responden kembali diberikan kuesioner sebagai data posttest.

\section{HASIL}

Karakteristik Responden 
Tabel 1. Distribusi karakteristik responden berdasarkan usia

\begin{tabular}{|c|c|c|c|c|c|c|}
\hline No & Kelc & & Mean & SD & $\begin{array}{c}\text { Minimum- } \\
\text { Maksimu } \\
\text { m }\end{array}$ & $\underset{\%}{C I ; 95}$ \\
\hline 1 & Book & 10 & 31,10 & 2,821 & $26-35$ & $\begin{array}{l}28,78- \\
32,82\end{array}$ \\
\hline 2 & Audio & 10 & 29,00 & 3,795 & 5 & $\begin{array}{c}26,09- \\
31,51\end{array}$ \\
\hline 3 & $\begin{array}{l}\text { Booklet \& } \\
\text { audiovisual }\end{array}$ & 10 & 30,70 & 3,917 & 2-34 & $\begin{array}{l}27,90- \\
33,50 \\
\end{array}$ \\
\hline
\end{tabular}

Berdasarkan tabel di atas dapat dijelaskan bahwa perbedaan usia responden antara kelompok yang diberi penyuluhan menggunakan media booklet, audiovisual, dan booklet \& audiovisual tidak jauh beda, dimana rata-rata usia responden pada kelompok booklet adalah 30,80 $\pm 2,821$ tahun dengan usia termuda 26 tahun dan usia paling tua adalah 35 tahun (IK;95\% 28,7832,82). Pada kelompok audiovisual rata-rata usia responden adalah 29,00 $\pm 3,795$ tahun dengan usia termuda 22 tahun dan paling tua adalah 35 tahun (IK;95\% 26,09-31,51). Sedangkan pada kelompok booklet \& audiovisual rata-rata usia responden adalah $30,70 \pm 3,917$ tahun dengan usia termuda 22 tahun dan paling tua adalah 34 tahun (IK;95\% 27,90-33,50)

Tabel 2. Distribusi karakteristik responden berdasarkan paritas, pendidikan, dan pekerjaan

\begin{tabular}{|c|c|c|c|c|c|}
\hline \multirow{3}{*}{ Variabel } & \multicolumn{3}{|c|}{ Kelompok } & \multirow{3}{*}{$N$} & \multirow{3}{*}{$\%$} \\
\hline & Booklet & $\begin{array}{c}\text { Audiovisu } \\
\text { al }\end{array}$ & $\begin{array}{c}\text { Booklet \& } \\
\text { Audiovisua } \\
l\end{array}$ & & \\
\hline & $F \quad \%$ & $\%$ & $\%$ & & \\
\hline
\end{tabular}

\begin{tabular}{|c|c|c|c|c|c|c|c|c|}
\hline Paritas & & & & & & & & \\
\hline Primi & 3 & 30,0 & 5 & 50,0 & 3 & 30,0 & 11 & 36,7 \\
\hline Multi & 7 & 70,0 & 5 & 50,0 & 7 & 70,0 & 19 & 63,3 \\
\hline Total & & & & & & & 30 & 100 \\
\hline Pendidikar & & & & & & & & \\
\hline Dasar & 4 & 40,0 & 5 & 50,0 & 3 & 30,0 & 12 & 40,0 \\
\hline Menengah & 4 & 40,0 & 4 & 40,0 & 3 & 30,0 & 11 & 36,7 \\
\hline Tinggi & 2 & 20,0 & 1 & 10,0 & 4 & 40,0 & 7 & 23,3 \\
\hline Total & & & & & & & 30 & 100 \\
\hline Pekerjaan & & & & & & & & \\
\hline $\begin{array}{l}\text { Tidak } \\
\text { bekeria }\end{array}$ & 5 & 50,0 & 5 & 50,0 & 4 & 40,0 & 14 & 46,7 \\
\hline Bekerja & 5 & 50,0 & 5 & 50,0 & 6 & 60,0 & 16 & 53,3 \\
\hline Total & & & & & & & 30 & 100 \\
\hline
\end{tabular}

Berdasarkan tabel di atas dapat diketahui bahwa karakteristik responden dilihat dari paritas sebagian besar adalah multigravida (63,3\%). Pada kelompok booklet dan kombinasi antara booklet \& audiovisual sebagian besar adalah multigravida dimana masing-masing sebanyak 7 orang $(70,0 \%)$, sementara pada kelompok audiovisual jumlah primigravida dan multigravida sama yaitu masing-masing 5 orang $(50,0 \%)$. Karakteristik responden dilihat dari tingkat pendidikan, sebagian besar responden memiliki jenjang pendidikan dasar (40,0\%), tertinggi kedua adalah menengah $(36,7 \%)$, dan selebihnya pendidikan tinggi (23,\%). Jenjang pendidikan pada kelompok booklet meliputi pendidikan dasar dan menengah masingmasing 4 orang $(40,0 \%)$, pendidikan tinggi 2 orang (20,0\%). Jenjang pendidikan kelompok audiovisual meliputi dasar 5 orang $(50,0 \%)$, menengah 4 orang $(40,0 \%)$, dan tinggi 1 orang $(10,0 \%)$. Sedangkan jenjang pendidikan pada kelompok 
kombinasi antara booklet \& audiovisual terdiri dari pendidikan dasar dan menengah masing-masing 3 orang $(30,0 \%)$ dan pendidikan tinggi 4 orang $(40,0 \%)$. Karakteristik responden berdasarkan pekerjaan sebagian besar bekerja yaitu sebesar 53,3\% dan yang tidak bekerja sebesar $46,7 \%$. Status pekerjaan responden pada kelompok booklet dan kelompok audiovisual masing-masing 5 orang (50,0\%) tidak bekerja dan 5 orang $(50,0 \%)$ bekerja. Sedangkan pada kelompok kombinasi booklet \& audiovisual terdapat 4 orang $(40,0 \%)$ yang tidak bekerja dan 6 orang $(60,0 \%)$ bekerja.

Tabel 3. Perbedaan pengetahuan ibu hamil tentang tanda bahaya kehamilan antara sebelum dan sesudah pemberian edukasi menggunakan media booklet, audiovisual dan media kombinasi (booklet \&

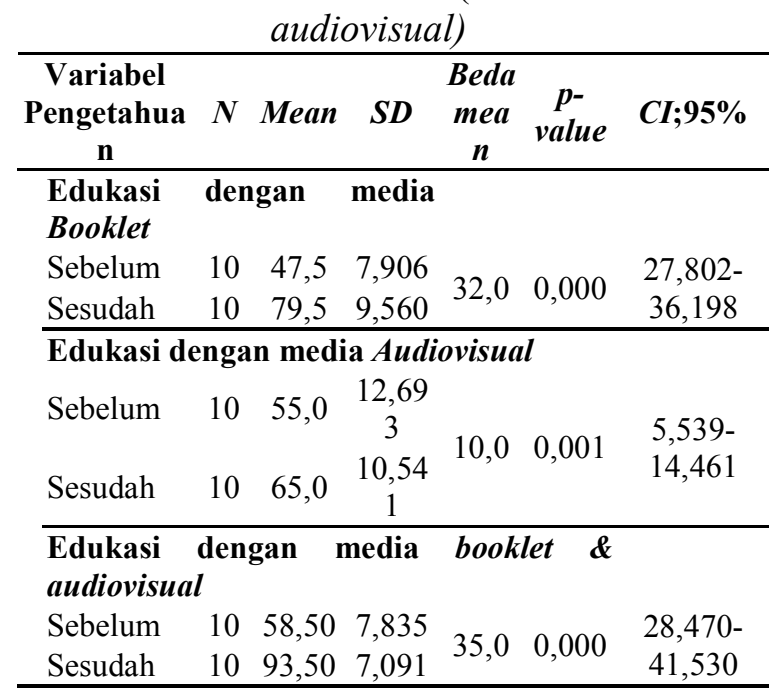

Berdasarkan tabel di atas dapat diketahui bahwa rata-rata pengetahuan ibu hamil tentang tanda bahaya kehamilan sebelum pemberian edukasi menggunakan media booklet adalah 47,5 $\pm 7,906$ dan setelah pemberian edukasi rata-rata skor pengetahuan ibu hamil adalah 79,5 $\pm 9,560$. Selisih rata-rata pengetahuan ibu hamil tentang tanda bahaya kehamilan antara sebelum dan sesudah pemberian edukasi dengan media booklet adalah 32,0 atau terjadi peningkatan sebesar $67,4 \%$. Hasil uji statistik menggunakan repeated sample $t$ test didapatkan $p$-value $0,000(\mathrm{p}-<\alpha 0,05)$ artinya pemberian edukasi menggunakan media booklet terbukti ada pengaruh meningkatkan pengetahuan ibu tentang tanda bahaya kehamilan. Rata-rata pengetahuan ibu hamil tentang tanda bahaya kehamilan sebelum pemberian edukasi menggunakan media audiovisual adalah $55,0 \pm 12,693$ dan setelah pemberian edukasi rata-rata skor pengetahuan ibu hamil adalah $65,0 \pm 10,541$. Selisih rata-rata pengetahuan ibu hamil tentang tanda bahaya kehamilan antara sebelum dan sesudah pemberian edukasi menggunakan media audiovisual adalah 10,0 atau terjadi peningkatan sebesar 18,9\%. Hasil uji statistik menggunakan repeated sample $t$ test didapatkan p-value $0,000(\mathrm{p}-<\alpha 0,05)$ artinya pemberian edukasi menggunakan media audiovisual terbukti ada pengaruh meningkatkan pengetahuan ibu tentang tanda bahaya kehamilan.

Rata-rata pengetahuan ibu hamil tentang tanda bahaya kehamilan sebelum 
pemberian edukasi menggunakan media kombinasi (booklet \& audiovisual) adalah $58,50 \pm 7,835$ dan setelah pemberian edukasi rata-rata skor pengetahuan ibu hamil adalah $93,50 \pm 7,091$. Selisih rata-rata pengetahuan ibu hamil tentang tanda bahaya kehamilan antara sebelum dan sesudah pemberian edukasi menggunakan media kombinasi (booklet \& audiovisual) adalah 35,0 atau terjadi peningkatan sebesar 59,8\%. Hasil uji statistik menggunakan repeated sample $t$ test didapatkan p-value $0,000(\mathrm{p}-<\alpha 0,05)$ artinya pemberian edukasi menggunakan media kombinasi (booklet \& audiovisual) terbukti ada pengaruh meningkatkan pengetahuan ibu tentang tanda bahaya kehamilan.

Tabel 4. Perbedaan sikap ibu hamil tentang tanda bahaya kehamilan antara sebelum dan sesudah pemberian edukasi menggunakan media booklet, audiovisual dan media kombinasi (booklet \& audiovisual)

\begin{tabular}{|c|c|c|c|c|}
\hline Variabel Sikap & N Mean & $S D$ & $\begin{array}{l}\text { Beda p- } \\
\text { mean value }\end{array}$ & CI;95\% \\
\hline \multicolumn{5}{|c|}{ Edukasi dengan media Booklet } \\
\hline Sebelum & 1050,4 & 3,658 & \multirow{2}{*}{29,9} & $23,56-$ \\
\hline Sesudah & 1080,3 & 10,242 & & 36,24 \\
\hline \multicolumn{5}{|c|}{ Edukasi dengan media Audiovisual } \\
\hline Sebelum & 1050,3 & 4,347 & \multirow{2}{*}{22,0} & $18,275-$ \\
\hline Sesudah & 1072,3 & 7,119 & & 25,725 \\
\hline \multicolumn{3}{|c|}{$\begin{array}{l}\text { Edukasi dengan } \\
\text { audiovisual }\end{array}$} & booklet & \\
\hline Sebelum & 1048,8 & 4,417 & \multirow{2}{*}{42,7} & $37,563-$ \\
\hline Sesudah & 1091,5 & 7,792 & & 47,837 \\
\hline
\end{tabular}

Berdasarkan tabel di atas dapat diketahui bahwa rata-rata sikap ibu hamil tentang tanda bahaya kehamilan sebelum pemberian edukasi menggunakan media booklet adalah 50,4 $\pm 3,658$ dan setelah pemberian edukasi rata-rata skor sikap ibu hamil adalah $80,3 \pm 10,242$. Selisih rata-rata sikap ibu hamil tentang tanda bahaya kehamilan antara sebelum dan sesudah pemberian edukasi dengan media booklet adalah 29,9 atau terjadi peningkatan sebesar 59,3\%. Hasil uji statistik menggunakan repeated sample $t$ test didapatkan $p$-value $0,000(\mathrm{p}<\alpha 0,05)$ artinya pemberian edukasi menggunakan media booklet terbukti ada pengaruh meningkatkan sikap ibu tentang tanda bahaya kehamilan.

Rata-rata sikap ibu hamil tentang tanda bahaya kehamilan sebelum pemberian edukasi menggunakan media audiovisual adalah $50,3 \pm 4,347$ dan setelah pemberian edukasi rata-rata skor sikap ibu hamil adalah $72,3 \pm 7,119$. Selisih rata-rata sikap ibu hamil tentang tanda bahaya kehamilan antara sebelum dan sesudah pemberian edukasi menggunakan media audiovisual adalah 22,0 atau terjadi peningkatan sebesar $43,7 \%$. Hasil uji statistik menggunakan repeated sample $t$ test didapatkan $p$-value 0,000 $(p<\alpha 0,05)$ artinya pemberian edukasi menggunakan media audiovisual terbukti ada pengaruh meningkatkan sikap ibu tentang tanda bahaya kehamilan.

Rata-rata sikap ibu hamil tentang tanda bahaya kehamilan sebelum pemberian edukasi menggunakan media kombinasi 
(booklet \& audiovisual) adalah 48,8 $\pm 4,417$ dan setelah pemberian edukasi rata-rata skor sikap ibu hamil adalah 91,5 $\pm 7,792$. Selisih rata-rata sikap ibu hamil tentang tanda bahaya kehamilan antara sebelum dan sesudah pemberian edukasi menggunakan media kombinasi (booklet \& audiovisual) adalah 42,7 atau terjadi peningkatan sebesar $87,5 \%$. Hasil uji statistik menggunakan repeated sample $t$ test didapatkan p-value $0,000(\mathrm{p}-<\alpha 0,05)$ artinya pemberian edukasi menggunakan media kombinasi (booklet \& audiovisual) terbukti ada pengaruh meningkatkan sikap ibu tentang tanda bahaya kehamilan.

Tabel 5. Perbedaan edukasi menggunakan media booklet, audiovisual dan kombinasi

(booklet \& audiovisual) terhadap pengetahuan ibu hamil tentang tanda bahaya kehamilan

\begin{tabular}{|c|c|c|c|c|}
\hline Variabel & $N$ & Mean $\pm S D$ & $\begin{array}{c}95 \% \text { CI for } \\
\text { Interval } \\
\text { Mean }\end{array}$ & p-value \\
\hline \multicolumn{5}{|c|}{ Pengetahuan Sebelum Intervensi } \\
\hline Booklet & 10 & $47,5 \pm 7,906$ & $41,84-53,16$ & \multirow{3}{*}{0,501} \\
\hline Audiovisual & 10 & $55,0 \pm 12,693$ & $45,92-64,08$ & \\
\hline $\begin{array}{l}\text { Booklet \& } \\
\text { audiovisual }\end{array}$ & 10 & $58,5 \pm 7,835$ & $52,90-64,10$ & \\
\hline \multicolumn{5}{|c|}{ Pengetahuan Setelah Intervensi } \\
\hline Booklet & 10 & $75,5 \pm 9,560$ & $72,66-83,64$ & \multirow{3}{*}{0,000} \\
\hline Audiovisual & 10 & $65,0 \pm 10,541$ & $57,46-72,54$ & \\
\hline $\begin{array}{l}\text { Booklet \& } \\
\text { audiovisual }\end{array}$ & 10 & $93,5 \pm 7,091$ & 8 & \\
\hline
\end{tabular}

Berdasarkan hasil uji statistik seperti terlihat pada tabel di atas dapat diketahui bahwa pada hasil uji one way Anova, sebelum intervensi rata-rata skor pengetahuan ibu hamil tentang tanda bahaya kehamilan antar kelompok perlakuan tidak berbeda nyata (p-value 0,501> $\alpha 0,05)$. Sedangkan setelah intervensi didapatkan $p$ value $0,000(\mathrm{p}<\alpha 0,05)$ artinya paling tidak terdapat dua kelompok yang memiliki pengaruh yang berbeda dalam meningkatkan pengetahuan ibu hamil tentang tanda bahaya kehamilan.

Tabel 7. Hasil Analisis Uji Post-hoc Variabel Pengetahuan

\begin{tabular}{|c|c|c|c|c|}
\hline Kelompok Variabel & $\begin{array}{l}\text { Beda } \\
\text { mean }\end{array}$ & $S E$ & $\begin{array}{c}C I \\
95 \%\end{array}$ & Sig. \\
\hline Booklet vs audiovisual & 14,5 & 4,105 & $\begin{array}{l}6,05- \\
22,92\end{array}$ & 0,002 \\
\hline $\begin{array}{l}\text { Kombinasi (booklet \& } \\
\text { audiovisual) vs booklet }\end{array}$ & 14,0 & 4,105 & $\begin{array}{l}5,58- \\
22,42\end{array}$ & 0,002 \\
\hline $\begin{array}{l}\text { Kombinasi (booklet \& } \\
\text { audiovisual) vs audiovisual }\end{array}$ & 28,5 & 4,105 & $\begin{array}{c}20,08- \\
36,96\end{array}$ & 0,000 \\
\hline
\end{tabular}

Berdasarkan tabel di atas dapat

diketahui bahwa perbedaan selisih rata-rata peningkatan pengetahuan ibu hamil antara kelompok yang diberi edukasi media booklet dengan kelompok yang diberi edukasi media audiovisual adalah 14,5 $\pm 4,105$. Pada hasil uji uji Post hoc didapatkan $p$-value $0,002(\mathrm{p}<\alpha 0,05)$ artinya perbedaan tingkat pengetahuan setelah perlakuan pada kedua kelompok berbeda signifikan yaitu edukasi menggunakan media booklet lebih berpengaruh dibandingkan menggunakan media audiovisual. Selisih rata-rata peningkatan pengetahuan ibu hamil antara kelompok yang diberi edukasi media kombinasi 
(booklet \& audiovisual) dengan kelompok yang diberi edukasi media booklet adalah 14,0 $\pm 4,105$. Pada hasil uji uji Post hoc didapatkan $p$-value $0,002(\mathrm{p}<\alpha 0,05)$ artinya perbedaan tingkat pengetahuan setelah perlakuan pada kedua kelompok berbeda signifikan yaitu edukasi menggunakan media kombinasi (booklet \& audiovisual) lebih berpengaruh dibandingkan menggunakan media booklet.

Selisih rata-rata peningkatan pengetahuan ibu hamil antara kelompok yang diberi edukasi media kombinasi (booklet \& audiovisual) dengan kelompok yang diberi edukasi media audiovisual adalah 28,5 $\pm 4,105$. Pada hasil uji uji Post hoc didapatkan p-value $0,000 \quad(\mathrm{p}<\alpha 0,05)$ artinya perbedaan tingkat pengetahuan setelah perlakuan pada kedua kelompok berbeda signifikan yaitu edukasi menggunakan media kombinasi (booklet \& audiovisual) lebih berpengaruh dibandingkan menggunakan media audiovisual.

Tabel 8. Perbedaan edukasi menggunakan media booklet, audiovisual dan kombinasi (booklet \& audiovisual) terhadap Sikap ibu hamil tentang tanda bahaya kehamilan

\begin{tabular}{|c|c|c|c|c|}
\hline Variabel & $N$ & $M e a n \pm S D$ & $\begin{array}{c}95 \% \text { CI for } \\
\text { Interval } \\
\text { Mean } \\
\end{array}$ & p-value \\
\hline \multicolumn{5}{|c|}{ Sikap Sebelum Intervensi } \\
\hline Booklet & 10 & $50,4 \pm 3,658$ & $47,78-53,02$ & \multirow{3}{*}{0,633} \\
\hline Audiovisual & 10 & $50,3 \pm 4,347$ & $47,19-53,41$ & \\
\hline $\begin{array}{l}\text { Booklet \& } \\
\text { audiovisual }\end{array}$ & 10 & $48,8 \pm 4,417$ & $45,64-51,96$ & \\
\hline \multicolumn{4}{|c|}{ Sikap Setelah Intervensi } & 0,000 \\
\hline
\end{tabular}

\begin{tabular}{lcccc}
\hline Variabel & $\boldsymbol{N}$ & Mean $\pm \boldsymbol{S D}$ & $\begin{array}{c}95 \% \text { CIfor } \\
\text { Interval p-value } \\
\text { Mean }\end{array}$ & p \\
\hline $\begin{array}{l}\text { Booklet } \\
\text { Audiovisual }\end{array}$ & 10 & $80,3 \pm 10,242$ & $72,97-87,63$ \\
$\begin{array}{l}\text { Booklet \& } \\
\text { audiovisual }\end{array}$ & 10 & $91,5 \pm 7,792$ & $85,93-97,07$ \\
\hline
\end{tabular}

Berdasarkan hasil uji statistik seperti terlihat pada tabel $5.10 \mathrm{di}$ atas dapat diketahui bahwa pada hasil uji one way Anova, sebelum intervensi rata-rata skor pengetahuan ibu hamil tentang tanda bahaya kehamilan antar kelompok perlakuan tidak berbeda nyata (p-value $0,633>\alpha 0,05)$. Sedangkan setelah intervensi didapatkan $p$ value $0,000(\mathrm{p}<\alpha 0,05)$ artinya paling tidak terdapat dua kelompok yang memiliki pengaruh yang berbeda dalam meningkatkan sikap ibu hamil tentang tanda bahaya kehamilan

Tabel 9. Hasil Analisis Uji Post-hoc Variabel Sikap

\begin{tabular}{|c|c|c|c|c|}
\hline Kelompok Variabel & $\begin{array}{l}\text { Beda } \\
\text { mean }\end{array}$ & $S E$ & $\begin{array}{c}C I \\
95 \%\end{array}$ & Sig. \\
\hline Booklet vs audiovisual & 8,0 & 3,797 & $\begin{array}{l}0,21- \\
15,79\end{array}$ & 0,045 \\
\hline $\begin{array}{l}\text { Kombinasi (booklet \& } \\
\text { audiovisual) vs booklet }\end{array}$ & 11,2 & 3,797 & $\begin{array}{l}3,41- \\
18,99\end{array}$ & 0,007 \\
\hline $\begin{array}{l}\text { Kombinasi (booklet \& } \\
\text { audiovisual) vs audiovisual }\end{array}$ & 19,2 & 3,797 & $\begin{array}{l}11,41- \\
26,99\end{array}$ & 0,000 \\
\hline
\end{tabular}

Berdasarkan tabel di atas dapat diketahui bahwa perbedaan selisih rata-rata peningkatan sikap ibu hamil antara kelompok yang diberi edukasi media booklet dengan kelompok yang diberi edukasi media audiovisual adalah 8,0 $\pm 3,797$. Pada hasil uji uji Post hoc didapatkan $p$-value $0,045(\mathrm{p}<\alpha 0,05)$ artinya 
setelah intervensi, rata-rata peningkatan sikap pada kedua kelompok berbeda signifikan, dimana edukasi menggunakan media booklet lebih berpengaruh dibandingkan menggunakan media audiovisual.

Perbedaan selisih rata-rata peningkatan sikap ibu hamil antara kelompok yang diberi edukasi media kombinasi (booklet \& audiovisual) dengan kelompok yang diberi edukasi media booklet adalah 11,2 $\pm 3,797$. Pada hasil uji Post hoc didapatkan p-value 0,007 $(\mathrm{p}<\alpha 0,05)$ artinya setelah intervensi, ratarata sikap pada kedua kelompok berbeda signifikan yaitu edukasi menggunakan media kombinasi (booklet \& audiovisual) lebih berpengaruh dibandingkan menggunakan media booklet terhadap peningkatan pengetahuan ibu hamil tentang tanda bahaya kehamilan.

Perbedaan selisih rata-rata peningkatan sikap ibu hamil antara kelompok yang diberi edukasi media kombinasi (booklet \& audiovisual) dengan kelompok yang diberi edukasi media audiovisual adalah 19,2 $\pm 3,797$. Pada hasil uji uji Post hoc didapatkan p-value 0,000 $(\mathrm{p}<\alpha 0,05)$ artinya setelah intervensi ratarata sikap ibu hamil pada kedua kelompok berbeda signifikan yaitu edukasi menggunakan media kombinasi (booklet \& audiovisual) lebih berpengaruh dibandingkan menggunakan media audiovisual terhadap peningkatan sikap ibu hamil tentang tanda bahaya kehamilan.

\section{PEMBAHASAN}

Pengaruh edukasi menggunakan media booklet terhadap pengetahuan ibu hamil tentang tanda bahaya kehamilan

Selisih rata-rata pengetahuan ibu hamil tentang tanda bahaya kehamilan antara sebelum dan sesudah pemberian edukasi dengan media booklet terjadi peningkatan. Disimpulkan bahwa pemberian edukasi menggunakan media booklet terbukti ada pengaruh meningkatkan pengetahuan ibu tentang tanda bahaya kehamilan. Hasil penelitian ini sejalan dengan penelitian Agustin Maria (2014) bahwa didapatkan hasil t- test sebesar $-9,853$ dan nilai $\mathrm{p}$ value 0,000 sehingga kesimpulannya adalah Ho ditolak yang artinya terdapat perbedaan pengetahuan antara sebelum dan sesudah dilakukan pendidikan kesehatan dengan media booklet.

Menurut Lestari (2015) pengetahuan adalah suatu proses mengingat dan mengenak kembali objek yang telah dipelajari melalui panca indra pada suatu bidang tertentu secara baik. Lebih lanjut Notoatmodjo (2010) mengungkapkan bahwa pengetahuan adalah hasil pengindraan manusia, atau hasil seseorang terhadap objek melalui indra yang dimilikinya (mata, 
hidung, telinga dan sebagainya). Suatu perbuatan yang didasari oleh pengetahuan akan lebih langgeng daripada perbuatan yang tidak didasari oleh pengetahuan. Menurut Notoatmodjo (2010) booklet adalah media penyampaian pesan-pesan kesehatan dalam bentuk buku, baik berupa tulisan maupun gambar. Booklet merupakan komunikasi massa yang bertujuan untuk menyampaikan pesan yang bersifat promosi, anjuranm larangan-larangan kepada khalayak massa dan berbentuk cetakan. Sehingga akhir dari tujuannya tersebut adalah masyarakat yaitu sebagai objek memahami dan menuruti pesan yang terkandung dalam media komunikasi massa tersebut. Kelebihan booklet antara lain tahan lama, dapat dibawa kemana-mana, mempermudah pemahaman, tidak perlu listrik dan bisa mencakup banyak orang. Media atau alat peraga adalah alat yang digunakan oleh pendidik untuk membantu dan menerangkan sesuatu dalam proses pendidikan atau pengajaran. Media bermanfaat menimbulkan minat sasaran, merangsang sasaran untuk meneruskan pesan pada orang lain, dan memudahkan penyampaian informasi ${ }^{8}$. Media booklet adalah buku yang tipis dan lengkap informasinya, yang memudahkan media tersebut untuk dibawa. Booklet berisi informasi yang jelas, tegas dan mudah dimengerti selain itu juga berisi tulisan dan gambar ${ }^{9}$

\section{Pengaruh edukasi menggunakan media} audiovisual terhadap pengetahuan ibu hamil tentang tanda bahaya kehamilan

Selisih rata-rata pengetahuan ibu hamil tentang tanda bahaya kehamilan antara sebelum dan sesudah pemberian edukasi menggunakan media audiovisual terjadi peningkatan. Disimpulkan bahwa pemberian edukasi menggunakan media audiovisual terbukti ada pengaruh meningkatkan pengetahuan ibu tentang tanda bahaya kehamilan. Hasil penelitian ini sejalan dengan penelitian Fatmah Zakaria (2017) bahwa ada peningkatan pengetahuan dan sikap setelah diberikan pendidikan kesehatan dengan media audiovisual terlihat pada nilai mean pengetahuan $15,8 \pm 0,34$ dan nilai mean sikap $12,8 \pm 0,37$ dengan nilai $p$ value $0,000<$ a 0,05 .

Pendidikan kesehatan dengan media atau alat peraga dapat mengubah pengetahuan melalui pancaindera yang ditangkap oleh seseorang ${ }^{10}$. Media audiovisual adalah alat bantu pendidikan yang dalam penggunaannya menstimulasi indera penglihtan dan pendengaran ${ }^{11}$.. Sedangkan menurut Arsyad (2014) media audiovisual merupakan alat bantu pendidikan yang memiliki unsur suara dan gambar, yang sifatnya mampu meningkatkan persepsi, 
mampu meningkatkan pengetahuan dan meningkatkan ingatan. Menurut Notoatmodjo (2010) jenis media elektronik ini mempunyai kemampuan yang lebih baik, karena meliputi kedua jenis media auditif (mendengar) dan visual (melihat). Audiovisual merupakan media yang mempunyai unsur suara dan unsur gambar.

\section{Pengaruh edukasi menggunakan media} kombinasi (booklet \& audiovisual) terhadap pengetahuan ibu hamil tentang tanda bahaya kehamilan

Selisih rata-rata pengetahuan ibu hamil tentang tanda bahaya kehamilan antara sebelum dan sesudah pemberian edukasi menggunakan media kombinasi (booklet \& audiovisual) terjadi peningkatan. Disimpulkan bahwa pemberian edukasi menggunakan media kombinasi (booklet \& audiovisual) terbukti ada pengaruh meningkatkan pengetahuan ibu tentang tanda bahaya kehamilan.

Hasil penelitian ini sesuai dengan penelitian yang dilakukan oleh Maria Agustin (2014) bahwa kedua media tersebut yaitu booklet dan audiovisual sama - sama efektif dapat meningkatkan pengetahuan. Berdasarakan besar nilai selisih yang begitu kecil dan didapat kesimpulan bahwa Ho diterima menunjukkan bahwa kedua media tersebut yaitu booklet dan audiovisual sama
- sama efektif dapat meningkatkan pengetahuan.

Pengetahuan seseorang terhadap objek mempunyai intensitas atau tingkat yang berbeda-beda. Menurut Budiman dan Riyanto (2013) mengungkapkan faktor yang dapat mempengaruhi pengetahuan diantaranya adalah sebagai berikut : pendidikan, informasi / media massa, sosial budaya dan ekonomi, lingkungan, pengalaman dan usia.

Kemungkinan ini bisa terjadi akibat setelah pendidikan kesehatan dilakukan, baik menggunakan media booklet maupun audiovisual dilakukan diskusi atau tanya jawab sehingga dapat mempengaruhi hasil pengisian pertanyaan kuesioner. Berkembangnya teknologi akan menyediakan bermacam- macam media yang dapat mempengaruhi pengetahuan masyarakat tentang inovasi baru, dan adanya inovasi baru mengenai suatu hal memberikan landasan kognitif baru bagi terbentuknya pengetahuan terhadap hal baru tersebut. Penggabungan menggunkan kedua media (booklet \& audiovisual) dalam memberikan pendidikan kesehatan terbukti effektif untuk meningkatkan pengetahuan.

Pengaruh edukasi menggunakan media booklet terhadap sikap ibu hamil tentang tanda bahaya kehamilan 
Selisih rata-rata sikap ibu hamil tentang tanda bahaya kehamilan antara sebelum dan sesudah pemberian edukasi dengan media booklet terjadi peningkatan. Disimpulkan bahwa pemberian edukasi menggunakan media booklet terbukti ada pengaruh meningkatkan sikap ibu tentang tanda bahaya kehamilan. Hasil penelitian ini sejalan dengan penelitian Sirait (2013) bahwa rerata sikap setelah fase pemberian informasi pada kelompok yang tidak diberi informasi dengan kelompok yang diberi informasi menunjukkan perbedaan yang bermakna $(p<0,05)$. Pemberian informasi menggunakan media booklet sangat bermanfaat dalam meningkatkan sikap orang tua ke arah yang positif.

Berdasarkan teori sikap adalah juga respons tertutup seseorang terhadap stimulus atau objek tertentu, yang sudah melibatkan faktor pendapat dan emosi yang bersangkutan. Newcomb salah seorang ahli psikologi sosial menyatakan, bahwa sikap merupakan kesiapan atau kesediaan untuk bertindak $^{6}$.

Pemberian edukasi pada ibu hamil merupakan salah satu cara dalam meningkatkan pengetahuan dan pemahaman ibu hamil dengan menanamkan pemahaman kognitif sehingga diharapkan terjadi perubahan perubahan kearah yang lebih positif dalam hal ini terhadap tatalaksana tanda bahaya kehamilan yang pada akhirnya akan mengarah pada perubahan perilaku kesehatan. Pemberian informasi menggunakan media booklet merupakan faktor yang dapat mempengaruhi ibu hamil dalam menentukan sikap, sehingga mampu mengambil keputusan tepat dalam tatalaksana tanda bahaya kehamilan.

\section{Pengaruh edukasi menggunakan media} audiovisual terhadap sikap ibu hamil tentang tanda bahaya kehamilan

Selisih rata-rata sikap ibu hamil tentang tanda bahaya kehamilan antara sebelum dan sesudah pemberian edukasi menggunakan media audiovisual terjadi peningkatan. Disimpulkan bahwa pemberian edukasi menggunakan media audiovisual terbukti ada pengaruh meningkatkan sikap ibu tentang tanda bahaya kehamilan.

Hasil penelitian ini sejalan dengan penelitian Kapti (2013) tentang efektifitas audiovisual sebagai media penyuluhan kesehatan terhadap peningkatan pengetahuan dan sikap ibu dalam tatalaksana balita dengan diare bahwa terdapat perbedaan sikap yang bermakna antara sebelum dan sesudah penyuluhan kesehatan dengan media audiovisual. (pengetahuan: $\quad \mathrm{p}=0,01 ; \alpha=0.05 ; \quad$ sikap: $\mathrm{p}=0,036 ; \alpha=0.05)$. Peneliti merekomendasikan penggunaan media audiovisual dalam kegiatan penyuluhan dalam upaya meningkatkan pengetahuan 
dan sikap ibu. Peningkatan pengetahuan dan sikap ibu setelah diberikan perlakuan merupakan akibat dari pemberian pendidikan kesehatan dengan media audiovisual. Dengan demikian media audiovisual sebagai media pendidikan kesehatan efektif digunakan untuk memberikan peningkatan pengetahuan kepada ibu dan merubah sikap ibu menjadi lebih baik.

Audiovisual merupakan media yang mempunyai unsur suara dan unsur gambar. Indra yang paling banyak menyalurkan pengetahuan kedalam otak adalah mata, kurang lebih $75-87 \%$ pengetahuan manusia diperoleh melalui mata sedangkan 13-25\% lainnya tersalurkan melalui indra yang lain. Jenis media ini mempunyai kemampuan yang lebih baik, karena meliputi kedua jenis media auditif (mendengar) dan visual (melihat). Audiovisual memiliki kelebihan sudah dikenal masyarakat, lebih mudah dipahami, lebih menarik karena ada suara dan gambar bergerak ${ }^{6}$. Informasi merupakan stimulus bagi ibu dan dasar bagi pengetahuan, sementara pengetahuan merupakan dasar bagi orang tua dalam menentukan sikap yang tepat dalam mengambil keputusan tentang tanda bahaya kehamilan.

Sunaryo (2013) menjelaskan pembentukan sikap dipengerahui oleh faktor internal yang berasal dari dalam diri individu, faktor ini meliputi motif dan sikap yang bekerja dalam diri inidividu pada saat itu, serta yang mengarahkan minat dan perhatian. Sedangkan faktor eksternal berasal dari luar individu, baik yang bersifat langsung individu dengan individu, individu dengan kelompok) dan tidak langsung (melalui perantara, seperti alat komunikasi dan media massa).

Pengaruh edukasi menggunakan media kombinasi (booklet \& audiovisual) terhadap sikap ibu hamil tentang tanda bahaya kehamilan

Selisih rata-rata sikap ibu hamil tentang tanda bahaya kehamilan antara sebelum dan sesudah pemberian edukasi menggunakan media kombinasi (booklet \& audiovisual) terjadi peningkatan. Disimpulkan bahwa pemberian edukasi menggunakan media kombinasi (booklet \& audiovisual) terbukti ada pengaruh meningkatkan sikap ibu tentang tanda bahaya kehamilan. Hasil penelitian ini sesuai dengan penelitian yang dilakukan oleh Kapti (2013) tentang media audiovisual dan penelitian Sirait (2013) tentang pemberian informasi menggunakan media booklet, dimana keduanya menyatakan bahwa media penyuluhan baik audiovisual maupun booklet sama-sama dapat merubah sikap kearah yang lebih baik. Peningkatan pengetahuan dan sikap ibu setelah diberi 
perlakuan merupakan akibat dari pemberian pendidikan kesehatan menggunakan media audiovisual dan booklet sebagai media pendidikan kesehatan yang efektif digunakan untuk meningkatkan pengetahuan serta sikap ibu hamil dalam tatalaksana tanda bahaya kehamilan.

Hal ini dikarenakan penggunaan media audiovisual yang memiliki pengaruh selain meningkatkan pemahaman dan perubahan sikap, penggunaan media audiovisual pada proses pembelajaran akan memberikan kesan yang menarik sehingga seseorang tidak mudah melupakan informasi yang telah diperoleh ${ }^{2}$. Ditambah dengan adanya media booklet responden dapat membaca informasi secara tertulis yang lebih lengkap dan dapat dibaca pada waktu senggang selama kehamilannya, sehingga dapat disimpulkan penggunaan kombinasi media dapat meningkatkan sikap ibu hamil dibandingkan dengan penggunaan media secara terpisah.

Notoatmodjo (2012) menjelaskan bahwa fokus utama pemberian pendidikan kesehatan adalah perubahan perilaku. Senada dengan penjelasan Nursalam \& Effendi (2010) menjelaskan tujuan pendidikan kesehatan adalah perubahan perilaku, dengan tujuan spesifik yaitu perubahan pengetahuan, sikap dan praktik untuk meningkatkan atau mempertahankan kesehatannya.
Perbedaan pengaruh edukasi menggunakan media booklet, audiovisual dan media kombinasi (booklet \& audiovisual) terhadap pengetahuan dan sikap ibu hamil tentang tanda bahaya kehamilan

Terdapat perbedaan edukasi menggunakan media booklet, audiovisual dan media kombinasi (booklet \& audiovisual) terhadap pengetahuan dan sikap ibu hamil tentang tanda bahaya kehamilan $(\mathrm{p}<\alpha 0,05)$. Media kombinasi (booklet \& audiovisual) lebih berpengaruh dibandingkan media booklet dan media audiovisual). Pemberian paket edukasi tanda bahaya kehamilan dengan menggunakan media kombinasi lebih efektif karena, jika informasi yang disampaikan hanya melalui satu media terkadang kurang menarik bagi individu sementara jika melalui media kombinasi tentunya individu dapat melihat dan mendengar secara langsung dalam proses penyuluhan. Namun demikian, hal ini tentunya disesuaikan dengan kondisi dari lokasi penyuluhan dimana saat lokasi penyuluhan mendukung untuk melakukan edukasi dengan media kombinasi maka hal tersebut akan lebih utama.

\section{KESIMPULAN}

Kesimpulan dari penelitian ini yaitu sebagian besar responden berusia antara 2235 tahun, paritas primi (36,7\%) multi 
$(63,3 \%)$, pendidikan dasar (40\%) menengah $(36,7 \%)$ dan tinggi $(23,3 \%)$, ibu bekerja $(53,3 \%)$ tidak bekerja $(46,7 \%)$. Terdapat pengaruh paket edukasi menggunakan media booklet, audiovisual kombinasi terhadap pengetahuan dan sikap ibu hamil tentang tanda bahaya kehamilan $(\mathrm{p}<\alpha 0,05)$. Terdapat perbedaan media paket edukasi tanda bahaya kehamilan terhadap peningkatan pengetahuan dan sikap $(\mathrm{p}<\alpha 0,05) . \quad$ Media booklet-audiovisual berada di peringkat pertama lebih berpengaruh dibandingkan media booklet dan audiovisual, yang berada di peringkat kedua media yang berpengaruh adalah booklet dan yang berada diperingkat ketiga adalah media audiovisual.

\section{DAFTAR PUSTAKA}

1. Kemenkes RI (2015). Kesehatan Dalam Kerangka Sustainable Development GOALS (SDGs). Jakarta : Kementerian Kesehatan RI

2. WHO (2016) Maternal Mortality. http://www.who.int/mediacentrel factsheets/fs348/en/

3. Kemenkes RI (2014). Profil Kesehatan Indonesia. Jakarta: Kementerian Kesehatan RI.

4. Kemenkes RI (2011) Buku Pedoman Pengenalan Tanda Bahaya Pada
Kehamilan, Persalinan dan Nifas.

Jakarta, Kementerian Kesehatan RI.

5. Notoatmodjo, S. (2011). Kesehatan

Masyarakat. Jakarta: Rineka Cipta

6. Notoatmodjo, S (2010). Promosi

Kesehatan Teori dan Apliaksi. Jakarta:

Rineka Cipta.

7. Potter Perry (2009). Fundamental of Nursing, Buku 1, Edisi : 7, Salemba Medika : Jakarta

8. Maulana, H.D.J. (2014). Promosi

Kesehatan. Jakarta : Penerbit Buku

Kedokteran EGC.

9. Suiraoka, I., \& Supariasa, I. (2012).

Media Pendidikan Kesehatan.

Yogyakarta: Graha Ilmu

10. Maulana, H.D.J. (2009). Promosi kesehatan. Jakarta: Penerbit Buku Kedokteran EGC.

11. Uno, Hamzah B., \& Lamatenggo, N. (2010). Teknologi Komunikasi Dan Informasi Pembelajaran. Jakarta: Bumi Aksara.

12. Maria, A. (2014). Efektifitas Pendidikan Kesehatan Media Booklet Dibandingkan Dengan Audiovisual Terhadap Pengetahuan Orangtua Tentang Karies Gigi Pada Anak Usia 59 Tahun Di Desa Makam Haji. Diakses dari http://eprints.ums.ac.id pada tanggal 06 Maret 2018 
13. Lestari, Titik (2015). Kumpulan Teori

Untuk Kajian Pustaka Penelitian

Kesehatan. Yogyakarta: Nuha Medika.

14. Zakaria, F (2017). Pengaruh Pendidikan

Kesehatan Dengan Media Audiovisual

Terhadap Pengetahuan Dan Sikap Ibu

Tentang Inisiasi Menyusu Dini Di Kota

Yogyakarta. Diakses dari

https://ejournal.unisayogya.ac.id pada

tanggal 06 Maret 2018

15. Arsyad, A. (2014). Media

Pemebelajaran. Jakarta : Rajawali Pers

16. Budiman dan Riyanto. A (2013). Kapita

Selekta Kuesioner. Jakarta: Salemba

Medika

17. Sirait, N.A.J (2013). Pemberian

Informasi Meningkatkan Pengetahuan,

Sikap Dan Keterampilan Orang Tua

Dalam Penanganan Demam Pada Anak.

Jurnal Keperawatan Indonesia, Volume

16. Diakses dari

https://media.neliti.com pada tanggal 08

Maret 2018

18. Kapti, R.E (2013). Efektifitas

Audiovisual Sebagai Media Penyuluhan

Kesehatan Terhadap Peningkatan

Pengetahuan Dan Sikap Ibu Dalam

Tatalaksana Balita Dengan Diare Di

Dua Rumah Sakit Kota Malang. Jurnal

Ilmu Keprawatan Volume 1. Diakses

dari

http://jik.ub.ac.id/index.php/jik/article/v

iew/52 pada tanggal 05 Maret 2018
19. Sunaryo (2013). Psikologi untuk

keperawatan. Jakarta : EGC

20. Effendy, N (2010). Dasar-dasar

Keperawatan Kesehatan Masyarakat.

Jakarta: EGC. 